\title{
Małżeństwo niechrześcijańskie i sektanckie w świetle prawa województw centralnych II Rzeczypospolitej
}

Regulacja małżeństwa na obszarze byłego Królestwa Kongresowego nie miała jednolitego charakteru. Prawo małżeńskie z 1836 r. uznawało walor religijny małżeństwa, którego unormowanie zostało w konsekwencji podporządkowane zasadom przyjętym w poszczególnych wyznaniach. Prawo to nie normowało jednak w takim samym stopniu małżeństw we wszystkich wyznaniach. Tylko wyznania chrześcijańskie posiadające największe znaczenie w Królestwie Kongresowym zyskały szczegółową regulację w ustawie państwowej (rozdz. I-IV). Małżeństwa niechrześcijańskie oraz tzw. małżeństwa sektanckie, tj. małżeństwa chrześcijańskie inne niż rzymskokatolickie, prawosławne, greko-katolickie, ewangelicko-augsburskie i ewangelicko-reformowane, zostały odmiennie uregulowane w rozdz. V. Kwestia przesłanek zawarcia i rozwiązania tych małżeństw została pozostawiona do rozstrzygnięcia ustawom religijnym poszczególnych związków wyznaniowych (art. 179 PM). Zawarcie małżeństwa musiały jednak poprzedzać zapowiedzi (art. 186 PM). Ślub mógł być udzielony przez duchownego przełożonego gminy lub starszego gminy duchownej, w której przyszli małżonkowie zamieszkiwali albo przez duchownego lub starszego gminy najbliższej (art. 185 PM).

Ustawa państwowa ingerowała w małżeństwa osób należących do tych wyznań w ograniczonym zakresie, w szczególności poprzez zastosowanie niektórych przepisów o małżeństwie katolików ${ }^{1}$. W ten sposób zastrzeżono monogamiczność małżeństwa (art. 181 PM). Kolejne odesłania do przepisów dla katolików dotyczyły kwestii wieku małżonków i zezwolenia na małżeństwo ojca bądź opiekuna (art. 180 PM). Odesłanie nie obejmowało jednak art. 8 PM, co powodowało, że odnośnie do wieku zastosowanie znajdowała tylko przeszkoda tamująca, związana z brakiem 18 lat dla mężczyzn i 16 dla

${ }^{1}$ W. Jaworski, Prawo cywilne na ziemiach polskich, T. 1, Prawo matżeńskie, Warszawa 1917, s. 157, wskazuje, że nie znajdowały zastosowania do małżeństw uregulowanych w rozdz. V przeszkody małżeńskie zamieszczone w art. 26 i 29 PM. 
kobiet $^{2}$. Wyjątek stanowiło odesłanie do art. 168 PM zamieszczonego w rozdziale o małżeństwie ewangelików, który przewidywał dla kobiet zakaz zawierania nowego małżeństwa przed upływem 10 miesięcy od ustania lub rozwiązania poprzedniego. Zastosowanie znajdowała także przeszkoda różności wiary, prowadząca do nieważności małżeństw chrześcijan z niechrześcijanami. Nieważność małżeństwa miała miejsce także w przypadku bigamii oraz bliskiego pokrewieństwa między małżonkami - małżeństwa między krewnymi w linii prostej oraz między rodzeństwem (art. 182 PM). W przypadkach tych małżeństwo podlegało zaskarżeniu ze strony prokuratora (art. 190 PM). Przeszkody te miały więc charakter przeszkód zrywających iuris publici. Prawo państwowe dopuszczało także, że właściwa dla przyszłych małżonków ustawa religijna może przewidywać przeszkodę pokrewieństwa w stopniach dalszych, aniżeli wynikało to z art. 182 PM.

Na obszarze byłego Królestwa Kongresowego tylko jedno wyznanie objęte regulacją rozdz. V posiadało tzw. samorząd metrykalny, czyli uprawnienie do prowadzenia rejestracji stanu cywilnego swoich członków. Było to wyznanie mariawickie. W wyznaniu tym metryka kościelna stanowiła jednocześnie akt stanu cywilnego, a przełożony parafii pełnił funkcję urzędnika stanu cywilnego. Samorząd metrykalny posiadały również wyznania: katolickie, prawosławne i ewangelickie. W przypadku tych wyznań podmiot przed którym zawierano małżeństwo, prowadził jednocześnie rejestrację stanu cywilnego. W przypadku pozostałych wyznań doszło do rozdzielenia tych funkcji. Były to wyznania sektanckie (bez mariawitów) oraz wyznania niechrześcijańskie. Rejestracja stanu cywilnego dla członków tych wyznań była prowadzona przez władze świeckie. Duchowny po udzieleniu ślubu nie sporządzał więc aktu małżeństwa ${ }^{3}$.

Ustawa państwowa przewidywała kontrolę urzędnika stanu cywilnego, który miał obowiązek zawiadomić o dostrzeżonych uchybieniach prokuratora (art. 188 PM). Małżeństwo było bowiem zawierane przed duchownym, który mógł naruszyć ustawę państwową. Duchowny podlegał odpowiedzialności przed sądem cywilnym, jeżeli udzielił ślubu wbrew przeszkodom prawa cywilnego (art. 191 PM). W grę wchodziła także odpowiedzialność karna. Według art. 413 Kodeksu Tagancewa osoba duchowna wyznania niechrześcijańskiego, świadomie biorąca udział w zawarciu małżeństwa, wymienionego w art. 408-412 KT oraz urzędnik, winny sporządzenia aktu zaświadczającego świadomie przeciwne prawu małżeństwo (art. 408-412 KT), podlegają karze więzienia na czas jednego roku do trzech lat lub więzienia do jednego roku${ }^{4}$.

${ }^{2}$ Ibidem, s. 156.

${ }^{3}$ J. Litwin, Prawo o aktach stanu cywilnego. Jego geneza i zasady przewodnie, „Demokratyczny Przegląd Prawniczy" z 1946 r., Nr 3-4, s. 26.

${ }^{4} \mathrm{Na}$ ten temat szerzej zob. W. Makowski, Kodeks Karny obowiazujacy tymczasowo na ziemiach b. zaboru rosyjskiego, Warszawa 1921, s. 418. 
Związek Muzułmański m. st. Warszawy w piśmie do Min. W. R. i O. P. z dnia 22 XII 1924 r. zajął w tej kwestii odmienne stanowisko:

...w myśl art. 92 Kod. Cyw. oraz uchwały Komitetu do Spraw Królestwa Polskiego 22/VI 1870 r. (Dz. Pr. LXX 262 p. 3) obowiązujących na terenie b. Król. Pol., Mułła mahometański nie jest urzędnikiem stanu cywilnego, lecz jeno osobą, wykonującą czynności ściśle religijne, czynności zaś urzędnika stanu cywilnego do spraw wyznania mahometańskiego, zostały powierzone policji... Zatem akty kościelne przez Mułłę sporządzone względnie czynności religijne przez niego dokonywane nie mają skutków prawnych o ile nie zostały następnie ujęte w formę aktów stanu cywilnego, sporządzonych przez uprawnioną do tego osobę tj. przez policję, z czego wynika, że akty przez Mułłę sporządzone same przez się mają znaczenie tylko religijne i jako takie nie mogą być przedmiotem dochodzenia karnego... Wobec powyższego wytoczenie sprawy karnej za pogwałcenie obowiązujących przepisów mogłoby mieć miejsce jedynie przeciwko czynnikom upoważnionym do sporządzania aktów stanu cywilnego wyznania mahometańskiego, którzy akceptowali i ujmowali w formę prawną akty względnie czynności dokonywane przez Mułłę, nie zaś przeciwko temu ostatniemu, który w tych wypadkach dokonywał jedynie czynności religijnych przez jego wyznanie niezabronionych ${ }^{5}$.

Stanowisko powyższe nie koresponduje z przepisami prawa małżeńskiego z 1836 r. o zawarciu małżeństwa niechrześcijańskiego, które mówią o dokonaniu czynności religijnych. W przypadku wyznania mojżeszowego i mahometańskiego małżeństwo w myśl art. 187 PM zawierane było przed rabinem lub imamem, który dopełniwszy obrzędu religijnego, winien udać się wraz z małżonkami do urzędnika stanu cywilnego w celu sporządzenia aktu małżeństwa. Przepis ten mówił jednak o narzeczonych zamiast o małżonkach. Sugerowało to, że małżeństwo jest zawarte dopiero z chwilą sporządzenia aktu stanu cywilnego. Odnosząc się do tej kwestii, SN słusznie uznał, że według art. 231 PM akt stanu cywilnego jest jedynie dowodem stwierdzającym istnienie małżeństwa, co prowadziło do wniosku, że akt małżeństwa, sporządzony przez urzędnika stanu cywilnego, nie jest aktem zawarcia małżeństwa, lecz jedynie dowodem jego zawarcia. W konsekwencji SN stwierdził, iż art. 187 PM, głosi wprawdzie, że do urzędnika stanu cywilnego zgłosić się powinien duchowny z narzeczonymi, to jednak użycie wyrażenia „,narzeczeni” przypisać należy jedynie nieścisłości redakcyjnej, gdyż dalszy ciąg tego artykułu świadczy, że prawodawca uznaje małżeństwo za zawarte. Przemawia za tym stanowiskiem także nałożenie przez ustawodawcę na urzędnika stanu cywilnego (art. 188 PM) obowiązku zbadania, czy małżeństwo nie zostało zawarte z naruszeniem prawa państwowego, z czego

\footnotetext{
${ }^{5}$ AAN, Min. W. R. i O. P., 49 i nast./1482.
} 
wynika, że małżeństwo zostaje zawarte przez dopełnienie obrzędu religijnego (Zb. Orz. 135/1922) $)^{6}$.

Prawo małżeńskie z 1836 r. określało zasady skutecznego zawarcia małżeństwa. Przesłanka nieistnienia małżeństwa została określona w art. 9 PM: „nie masz małżeństwa tam, gdzie nie zachodzi obydwóch stron zezwolenie" Przepis ten zamieszczono w rozdz. I dotyczącym małżeństw osób wyznania rzymskokatolickiego. Wyłącznie w tym rozdziale zostały wskazane przypadki wad zezwolenia (art. 10-14 PM) ${ }^{8}$. Ogólna norma art. 9 PM znajdowała zastosowanie także do małżeństw w pozostałych wyznaniach, z wyjątkiem prawosławnego, ale $\mathrm{w}$ tym przypadku przepisy o małżeństwie prawosławnych przewidywały analogiczne postanowienie w art. 99 ust. 2 PM.

Do wyznań uregulowanych w rozdz. V zastosowanie art. 9 przewidywał art. 180 PM. Ponieważ przypadki wad zezwolenia i ich konsekwencje nie zostały przytoczone w rozdziałach traktujących o innych wyznaniach, lecz tylko w rozdziale o małżeństwie katolików, względem art. 9 stosowano interpretację autentyczną, zaczerpniętą z katolickiego prawa kanonicznego. W pozostałym zakresie SN zaakceptował pogląd, że przepis ten, stosownie do art. 180 PM, posiada treść samodzielną bez żadnej zależności od treści art. 10-14 PM, zamieszczonych w rozdziale o małżeństwie katolików. Stąd też SN uznał, że

${ }^{6}$ AAN, Min. W. R. i O. P., 58/1482. Na tle jednej ze spraw karnych, toczącej się w latach dwudziestych, forsowany był pogląd, który nie odpowiadał wykładni przyjętej przez SN. Uznano mianowicie, że do zaistnienia małżeństwa w prawie cywilnym niezbędne jest odbycie nie tylko ceremonii religijnej, a mianowicie że ,z art. 187 i 231 pr. o małż. KC ważne małżeństwo, między osobami, wyznającemi religję mahometańską, powinno być zawarte przez dokonanie dwóch aktów: 1) przez dopełnienie obrzędu religijnego przed Imamem i 2) przez sporządzenie aktu małżeństwa w obecności urzędnika stanu cywilnego". Niedojście do skutku obu aktów prowadziło do wniosku, że małżeństwo nie zaistniało, a w konsekwencji nie ma podstawy do pociągnięcia mułły do odpowiedzialności karnej za udzielenie ślubu bigamicznego (art. $412 \mathrm{KK}$ ). Fakt jednak, że w sprawie tej mułła nie udał się wraz ze świadkami do urzędnika stanu cywilnego nie miał znaczenia z punktu widzenia istnienia małżeństwa, które było zawarte już z chwilą dokonania pierwszego z wymienionych aktów.

${ }^{7}$ W. Jaworski, Prawo cywilne na ziemiach polskich, T. 1, s. 52 i 170, podaje, że prawo małżeńskie z 1836 r. przejęło z Kodeksu Napoleona koncepcję małżeństw nieistniejących, a więc takich małżeństw, ,gdzie zachodzi przypadek nie wadliwości zezwolenia, ale gdzie konieczne do powstania małżeństwa zezwolenie w ogóle nie zaistniało". Chodzi tu o sytuacje, gdy kobieta i mężczyzna nie wyrazili „nigdy i nigdzie przyzwolenia na małżeństwo, albo złożyli to oświadczenie, lecz nie w sposób przepisany ustawą". Do małżeństw nieistniejących autor zaliczał: 1) konkubinat; 2) żydowskie małżeństwo rytualne w Austrii; 3) małżeństwo nieważne z powodu braku formy i nie wpisane w rejestr małżeństw w Niemczech; 4) tak zwane matrimonium conscientiae; 5) związek dwóch osób, z których jedna okazuje się hermafrodytą; 6) nieważne małżeństwo po unieważnieniu, jeżeli małżonkowie się nie rozeszli.

${ }^{8}$ S. Tylbor, Matżeńskie Prawo, (w:) Encyklopedia Prawa Prywatnego pod red. Zolla-Wasilkowskiego, s. 751, podaje, że ,przepisy o wzajemnym zezwoleniu stron na zawarcie małżeństwa zostały szczegółowo opracowane tylko w rozdziale, odnoszącym się do małżeństw wyznania rzymsko-katolickiego. Postanowień traktujących o zezwoleniu na zawarcie małżeństwa, jeśli chodzi o inne wyznania chrześcijańskie, $\mathrm{z}$ wyjątkiem jednego przepisu, nie spotykamy w prawie o małżeństwie z r. 1836". 
nie ma podstawy do interpretacji art. 9 PM na zasadach Canonów 1086 par. 2, 1092 p. 2 Juris Canonicis w wypadku stosowania wspomnianego art. 9 do makżeństw osób wyznania mojżeszowego; Sądy duchowne katolickie, opierając się na przepisach kodeksu prawa kanonicznego, mają na względzie, że małżeństwo jest sakramentem i pod tym kątem interpretują pojęcie „zezwolenia stron” z art. 9, a w związku z tym mają możność interpretować i uzasadniać ważność sakramentu ślubu od tego, czy strona, przystępująca do niego, nie wykluczyła swoim uprzednim czynem lub aktem woli istotnych cech sakramentu, do którego przystąpiła; tymczasem przy małżeństwie wyznania mojżeszowego żaden sakrament nie dopełnia się, wobec czego przepisy prawa małżeńskiego z 1836 r., właściwe dla osób religii żydowskiej, nie mogą być interpretowane w myśl zasad prawa kanonicznego rzymsko-katolickiego ${ }^{9}$.

Ocena ważności małżeństwa opierać się powinna na przepisach prawa małżeńskiego z $1836 \mathrm{r}$. i w zakresie, w jakim prawo to odsyła do prawa religijnego, na prawie wewnętrznym związku wyznaniowego. W kwestii wad zezwolenia i ich wpływu na byt prawny małżeństwa, wobec szczegółowego unormowania tego zagadnienia tylko w przepisach o małżeństwie katolików, miarodajne dla pozostałych małżeństw było odnośne prawo religijne. W literaturze wyrażono także pogląd, że co do małżeństw osób należących do wyznań objętych jurysdykcją sądu powszechnego (rozdz. V) do oceny ważności małżeństwa mogły znaleźć zastosowanie przepisy Kodeksu Zobowiązań o oświadczeniach woli ${ }^{10}$. Wydaje się jednak, że przepisy te mogły znaleźć zastosowanie tylko wówczas, gdy ustawy religijne, do których odsyłał art. 179 PM, nie regulowały kwestii wad zezwolenia na małżeństwo.

Wyznania objęte rozdz. V miały zróżnicowany charakter. Wspólne było dla nich jedynie rozwiązanie w postaci nieprzyznania im uprawnienia do rozstrzygania spraw małżeńskich swoich członków ze skutkiem wobec państwa. W konsekwencji prawo małżeńskie z $1836 \mathrm{r}$. wyodrębniło w rozdz. V grupę wyznań, którym nie powierzono jurysdykcji w sprawach małżeńskich. W tej grupie mieściły się zarówno nowe związki religijne, niezdolne do stworzenia własnej organizacji sądowej, jak i wyznania o wielowiekowej tradycji, posiadające organy sądowe kompetentne w sprawach małżeńskich. Przykładem takiego organu był sąd rabinacki. Sąd rabinacki nie posiadał wprawdzie jurysdykcji cywilnej w Królestwie Kongresowym, w zakresie wyznaniowym mógł jednak orzekać w sprawie rozwodowej. Był to swego rodzaju arbitraż małżeński, wykonujący swoją funkcję w ramach uprawnień samorządowych, które

${ }^{9}$ GSW Nr 17/1939, s. 242-244.

${ }^{10} \mathrm{~S}$. Tylbor, Prawo matżeńskie, s. 751, podaje, że „,o do wyznań chrześcijańskich poza katolickiem oraz co do niechrześcijańskich znajdą zastosowanie przepisy ich prawa religijnego, a w tych małżeństwach, co do oceny ważności których są powołane sądy cywilne - w braku ścisłych norm w tej kwestji w prawie religijnym danego wyznania, sądy kierowaćby się mogły w drodze analogji niektóremi z zasad, zawartych w dziale o oświadczeniu woli w Kodeksie Zobowiązań”. 
przysługiwały wyznaniu mojżeszowemu w II Rzeczypospolitej. W praktyce rabin po udzieleniu rozwodu religijnego wystawiał stosowne zaświadczenie dla małżonków oraz pouczał ich o wymogach prawa cywilnego odnośnie rozwodu małżeństwa mojżeszowego w sądzie powszechnym ${ }^{11}$.

$\mathrm{Z}$ religijnego punktu widzenia uzyskanie rozwodu w sądzie rabinackim było jednak koniecznością dla osób wyznania mojżeszowego. W przeciwnym razie na podstawie wyroku sądu powszechnego osoby te nie otrzymałyby ślubu religijnego w wyznaniu mojżeszowym, a tylko ślub religijny mógł mieć skutki cywilne na obszarze byłego Królestwa Kongresowego. Wynikało to z przyjętej w dekrecie z 1836 r. metody regulacji małżeństwa, której konsekwencją było sprzężenie skutku cywilnego i wyznaniowego. Kodeks cywilny z 1825 r. przewidywał możliwość zawarcia małżeństwa bez obrządku religijnego, w sytuacji gdy obrządek ten nie był wymagany (art. $92 \mathrm{KCP}$ ). Należy jednak przyjąć, że wzmiankowane sprzężenie musiało wystąpić także wówczas, gdy prawo związku wyznaniowego, do którego odsyłał art. 179 PM, nie wymagało obrządku religijnego w celu zawarcia małżeństwa ${ }^{12}$.

Małżeństwo cywilne nie mogło powstać bez skutku wyznaniowego, a uchylenie skutku wyznaniowego przez właściwy sąd konsystorski co do zasady pociągało za sobą upadek skutku cywilnego. W przypadku małżeństw osób należących do wyznań uregulowanych w rozdz. V nie orzekały jednak sądy wyznaniowe, a rozwód rabinacki z państwowego punktu widzenia nie miał znaczenia. SN podkreślił, że nie ma w województwach centralnych wyroków wydanych przez rabinów, nie ma jurysdykcji rabinicznej i nie ma napomnień, udzielanych przez rabinów (Zb. Orz. 70/1924) ${ }^{13}$. O ile zatem powstanie obu wzmiankowanych skutków następowało z chwilą zawarcia małżeństwa, o tyle ich ustanie nie musiało nastąpić jednocześnie.

W rezultacie konstrukcja małżeństwa przyjęta $\mathrm{w}$ dekrecie mikołajewskim uległa modyfikacji. Pozostała w mocy zasada, że skutek cywilny małżeństwa nie mógł powstać bez skutku wyznaniowego, ale możliwe było uchylenie skutku cywilnego bez uchylenia skutku wyznaniowego. Sąd państwowy był bowiem władny orzec rozwód bez poprzedzającego rozwodu religijnego i bez uprzedniego napomnienia winnego małżonka przez rabina. W takim przypadku

${ }^{11} \mathrm{Na}$ ten temat szerzej zob. I. Szwarcman, A. Rżewski, Przewodnik dla urzędów stanu cywilnego, Łódź 1923.

${ }^{12}$ Należy przyjąć, że do zaistnienia skutku cywilnego małżeństwa niezbędne było powstanie jego skutku wyznaniowego także w przypadku przewidzianym w art. $92 \mathrm{KCP}$, a mianowicie, gdy przepisy religijne danego związku wyznaniowego nie wymagały obrządku religijnego w celu zawarcia małżeństwa. W literaturze międzywojennej pojawił się pogląd dopuszczający zawarcie małżeństwa na podstawie art. $92 \mathrm{KCP}$ i 179 PM jedynie poprzez sporządzenie aktu stanu cywilnego.

${ }^{13}$ Rozstrzygnięcie to odpowiada art. 1619 UPC stanowiącemu, że „oprócz spraw, wymienionych $w$ art. 1337, jurysdykcji sądu cywilnego ulegają również sprawy o unieważnienie i rozwiązanie małżeństwa osób, należących do tych wyznań, do których stosuje się rozdział V prawa o małżeństwie z roku 1836". 
kolejne małżeństwo zawarte w innej części państwa przez rozwiedzionych małżonków (jedynie na podstawie rozwodu cywilnego) było w pełni skuteczne.

Spośród pozostałych wyznań zaliczanych do omawianej grupy wymienić można zarówno wyznania chrześcijańskie, jak i niechrześcijańskie. Pierwsze określano potocznie mianem sektanckich (np. baptyści, adwentyści dnia siódmego, badacze Pisma św.). Drugie nie miały, poza wyznaniem mojżeszowym, istotnego znaczenia w Królestwie Kongresowym. Orzecznictwo kościelne, jeżeli w ogóle je wykonywano, pozbawione było skutków cywilnych.

Przed odzyskaniem niepodległości przyjęto $\mathrm{w}$ niechrześcijańskich i sektanckich sprawach rozwodowych właściwość sądu okręgowego w obrębie, którego małżeństwo zostało zawarte i powód zamieszkuje, z wyjątkiem spraw dotyczących naruszenia wiary małżeńskiej i niezdolności pożycia małżeńskiego $^{14}$. Kwestia właściwości wyznaniowej i przedmiotowej sądu w sprawie małżeńskiej stanowiła także przedmiot regulacji prawa małżeńskiego z 1836 r. Chodziło bowiem o rozstrzygnięcie, które prawo materialne ma stanowić podstawę orzeczenia $\mathrm{w}$ sprawie rozwodowej. Jeżeli sprawa dotyczyła małżeństwa mieszanego wyznaniowo, to art. 189 PM przewidywał właściwość ustawy religijnej strony powodowej. Reguła ta nie budziła wątpliwości, jeżeli obaj małżonkowie należeli do wyznań objętych rozdz. V, czyli jeden był na przykład mariawitą, drugi zaś adwentystą. Komisja Rządowa Sprawiedliwości w Instrukcji dla Trybunatów co do składania raportów o sprawach matżeńskich wyznań niechrześcijańskich z 28 VIII/9 IX 1839 r. ograniczała bowiem zastosowanie art. 189 PM do małżeństw pomiędzy członkami wyznań objętych rozdz. $V^{15}$. Poglądy prezentowane w doktrynie międzywojennej niejednokrotnie odbiegały od tego stanowiska. Zdaniem H. Świątkowskiego, kompetencja sądu wyznania strony powodowej (art. 189 PM) obowiązywała we wszystkich sprawach międzywyznaniowych, z wyjątkiem małżeństw od samego początku mieszanych, do których zastosowanie miał znajdować art. $196 \mathrm{PM}^{16}$. Według H. Świątkowskiego właściwość w sprawie rozwodowej sądu strony powodowej (art. 189 PM) zależała więc od tego, czy nie było to małżeństwo mieszane wyznaniowo ab initio, a nie od tego, czy małżonkowie należeli do wyznań objętych rozdz. V.

H. Świątkowski był zatem zdania, że art. 189 PM nie reguluje wyłącznie właściwości prawa materialnego w sprawie małżeńskiej, lecz również reguluje właściwość sądu w oparciu o wyznanie strony powodowej. Przynależność strony powodowej do wyznania objętego regulacją rozdz. V pociągała za sobą właściwość sądu powszechnego. Rozumowanie to odpowiadało zasa-

${ }^{14}$ Skurzalski, Jurysprudencja cywilna w streszczeniu 1842-1895 systematycznie ułożona (1895), s. 32 .

${ }^{15}$ Zbiór przepisów administracyjnych Królestwa Polskiego, Wydziat Sprawiedliwości, b. m. 1866, T. IV, s. 371 i nast.

${ }^{16}$ H. Świątkowski, Z praktyki sądu konsystorskiego, „Głos Sądownictwa” nr 2/1938, s. 111. 
dzie obowiązującej przy określeniu właściwości sądu kościelnego na podstawie art. 196 PM, który przyjmując właściwość sądu wyznania strony pozwanej, przesądzał jednocześnie o właściwości prawa materialnego w sprawie rozwodowej.

Przyjęcie wykładni zaproponowanej przez H. Świątkowskiego umożliwiałoby osobie wyznania rzymskokatolickiego wyeliminowanie orzecznictwa kościelnego w sprawie małżeńskiej przez przejście na wyznanie objęte regulacją rozdz. V. Nie ulega wątpliwości, że część przedstawicieli nauki prawa dążyła do przeforsowania takiej wykładni przepisów międzywyznaniowych, która doprowadziłaby do marginalizacji jurysdykcji sądów kościelnych. Taki cel przyświecał z pewnością J. Gwiazdomorskiemu, który sformułował pogląd o ograniczonej delegacji sądów kościelnych, oznaczający brak jurysdykcji cywilnej tych sądów, jeżeli przynajmniej jedna ze stron należy do wyznania objętego rozdz. $\mathrm{V}^{17}$. Jednocześnie dostrzegalna była tendencja do marginalizowania zasady właściwości sądu strony powodowej na rzecz zasady właściwości sądu strony pozwanej. Tej właśnie zasadzie SN nadał pierwszoplanowe znaczenie $\mathrm{w}$ orzeczeniu w sprawie małżeństwa Bremerów, formułując tezę o jej związku z równouprawnieniem wyznań (Zb. Orz. $172 / 1926)^{18}$. W konsekwencji zasada właściwości sądu strony pozwanej (art. 196 PM) przeważyła w praktyce międzywojennej. U schyłku Polski sanacyjnej SN ograniczył zastosowanie także i tej zasady, stwierdzając, że art. 196 PM nie znajduje zastosowania w sprawie separacyjnej, pomiędzy pozwaną adwentystką (w chwili zawarcia małżeństwa katoliczka), a powodem - katolikiem (Zb. Orz. 294/1939).

Orzeczenie powyższe stwierdzało w praktyce uchylenie art. $196 \mathrm{w}$ zakresie spraw separacyjnych. Ponieważ sądem separacyjnym mógł być jedynie sąd duchowny katolicki, rozstrzygnięcie to prowadziło do ukształtowania się mechanizmu, według którego sąd ten był właściwy w każdym przypadku skierowania do niego powództwa separacyjnego. W tym stanie rzeczy wyznanie pozwanego nie miało znaczenia. Orzeczenie to stanowiło więc wyraźne odstępstwo od zasad prawa międzywyznaniowego. Uznanie wiążącego charakte-

17 J. Gwiazdomorski, Skuteczność orzeczeń sadów duchownych b. Król. Kongr. w sprawach matżeńskich wobec prawa państwowego. PPA, T. LVII (1932), s. 15-16.

${ }^{18} \mathrm{SN}$ uznał mianowicie, że relacja pomiędzy wyznaniami jest rzeczą polityki prawodawczej, układu stosunków w państwie, tradycji historycznej... Możliwa więc jest bądź zupełna supremacja jednego wyznania nad wszystkimi innymi, jak to stanowiły względem religii prawosławnej przepisy zawarte w art. 199-201, 203 i 204 PM (w brzmieniu z r. 1891), które z odrodzeniem państwowości polskiej, jako z nią sprzeczne, utraciły moc przez sam fakt odzyskania tej państwowości, bądź też względna przewaga i wyższość jednego wyznania nad innymi, jak to miało miejsce względem religii rzymsko-katolickiej w stosunku do innych wyznań chrześcijańskich w powołanym prawie według art. 196, w dawnym brzmieniu z przed r. 1891, oraz uchylonych w 1891 r. przepisów art. 197, 204 i 205, bądź wreszcie pewna równowaga prawna pomiędzy wyznaniami, jaką wprowadza art. 196 PM w brzmieniu nadanym mu przez zdanie Rady Państwa z 1891 r. 
ru art. 196 przez SN w sprawie Bremerów, w kontekście powyższej wykładni tego artykułu, traciło względem Kościoła rzymskokatolickiego na znaczeniu. Innymi słowy, Kościół rzymskokatolicki mógł nie tylko unieważnić, ale i separować małżeństwo zawarte w jego obliczu. Przeciwnie, konsystorz ewangelicki mógł rozwiązać małżeństwo tylko wtedy, gdy pozwanym był ewangelik.

Jeżeli małżeństwo było jednolite wyznaniowo, sąd stosował prawo tego wyznania, do którego małżonkowie należeli. Sąd powszechny orzekał zatem rozwód małżeństwa żydowskiego na podstawie prawa mojżeszowego (art. 189 PM). Rozwód tego małżeństwa w sądzie konsystorskim był możliwy tylko wówczas, gdy jeden z małżonków przyjął wyznanie chrześcijańskie, uzasadniając tym samym właściwość konsystorza w sprawie rozwodowej. W przypadku przejścia na wyznanie ewangelickie, sąd tego wyznania mógł orzekać w sprawie rozwodowej, jeżeli pozwanym był ten małżonek, który przyjął wyznanie ewangelickie (art. $196 \mathrm{PM}$ ). W przypadku orzecznictwa kościelnego właściwość sądu pociągała za sobą właściwość prawa materialnego. Sąd konsystorski, kalwiński bądź luterański, orzekał rozwód na podstawie przepisów o małżeństwie ewangelików, zamieszczonych w rozdz. IV prawa małżeńskiego z 1836 r. W sprawie toczącej się z powództwa Flory z Segalów Baruchsonowej, Sąd Konsystorski Ewangelicko-Reformowany w Warszawie orzekł 14 września 1922 r. rozwód z powodu złośliwego opuszczenia, małżeństwa zawartego 13/26 X 1898 r. - jak stwierdzono w wyroku - przed Urzędnikiem Stanu Cywilnego dla wyznań niechrześcijańskich okręgu mokotowskiego w Warszawie. W chwili wytoczenia sprawy powódka była wyznania mojżeszowego, pozwany Jeannot Baruchson - kalwinem. Uprzednio w podaniu do Naczelnika Państwa, dotyczącym skrócenia rocznego terminu zapozwu z art. 156 PM, adwokat Mikołaj Silberstein działający w imieniu powódki, zaznaczył, że sprawa ta podlega jurysdykcji Sądu Konsystorskiego Ewangelicko-Reformowanego, gdyż mąż jej do tego wyznania należy ${ }^{19}$.

Kwestia właściwości sądu w sprawie małżeństwa z udziałem osoby wyznania objętego rozdz. V budziła jednak wątpliwości. Prawo międzywyznaniowe dekretu z 1836 r. uregulowało tylko niektóre przypadki małżeństw mieszanych. Ustawodawca interesował się przede wszystkim małżeństwami z katolikami i prawosławnymi. Pozostałe konfiguracje związków mieszanych zostały w zasadzie pominięte. W prawie z $1836 \mathrm{r}$. nie znajdujemy odrębnych zasad rządzących małżeństwami z ewangelikami. Chodzi tu w szczególności o małżeństwa ewangelików z przedstawicielami wyznań chrześcijańskich, objętych rozdz. V. W przypadkach nieuregulowanych, posługiwano się analogią do przepisów prawa międzywyznaniowego, zawartych w oddziale I rozdz. VI (art. 198 w zw. z art. 196 PM), co oznaczało stosowanie zasady właściwości sądu strony pozwanej.

${ }^{19}$ AAN, Min. W. R i O. P., s. 303 i 273/1347. 
Ustawodawca uregulował małżeństwa katolików z chrześcijanami objętymi rozdz. V (tzw. sektantami), postanawiając w art. 198 o zastosowaniu względem nich zasad obowiązujących małżeństwa katolicko-ewangelickie. Słuszne byłoby zatem stanowisko ogólnego zebrania departamentów Senatu Rządzącego z 1913 r. (15/1913), w myśl którego art. 196 PM ma zastosowanie $\mathrm{w}$ sprawie małżeńskiej między małżonkiem katolickim a małżonkiem marjawickim. Z uwagi na to rozstrzygnięcie, małżeństwa pomiędzy osobami należącymi do wyznań objętych rozdz. I-IV a chrześcijanami - sektantami można podzielić na dwie grupy:

1. małżeństwa katolicko-sektanckie, do których stosują się zasady dotyczące małżeństw katolicko-ewangelickich;

2. małżeństwa mieszane chrześcijan - akatolików, gdy tylko jeden z nich należy do wyznania objętego jurysdykcją konsystorską, i nie jest to wyznanie prawosławne.

O ile zatem w przypadku małżeństw pierwszej grupy prawo zawiera odesłanie do art. 196 PM, o tyle w odniesieniu do drugiej grupy małżeństw brak takiego odesłania. Brak więc podstaw do tego, by zasady rządzące związkami między osobami należącymi do tych wyznań, których małżeństwo zostało uregulowane w prawie międzywyznaniowym, przenosić mechanicznie na związki osób należących do takich wyznań, których małżeństwo pominięto milczeniem.

Kwestia małżeństw z sektantami już w początkach niepodległości wzbudzała wątpliwości nie tylko w doktrynie, lecz również w sferach rządowych. Wyodrębnienie się z katolicyzmu na początku XX w. wyznania marjawickiego, kwestię właściwości sądu uczyniło niezwykle drażliwą. Marjawityzm został wprawdzie uznany przez rząd rosyjski, ale nie uzyskał jurysdykcji cywilnej w sprawach małżeńskich. Pożądanym rozwiązaniem kwestii forum sądowego dla członków nowego wyznania było wykluczenie względem nich jurysdykcji konsystorskiej. Skutek ten można było osiągnąć, poddając sprawy małżeńskie marjawitów sądom powszechnym na podstawie art. 189 PM. Niestety, art. 198 PM przewidywał w sprawach małżeństw katolicko-sektanckich zastosowanie art. 196 PM.

Stanowisko władz administracyjnych odrodzonej Polski było w kwestii forum sądowego dla marjawitów niejednolite. Na tle prośby Bolesława Winiarskiego o przekazanie jego sprawy rozwodowej do konsystorza marjawickiego ujawniły się poważne rozbieżności pomiędzy resortami sprawiedliwości i wyznań religijnych. W sprawie tej Ministerstwo W. R. i O. P. wystąpiło do Ministerstwa Sprawiedliwości o zajęcie stanowiska. Według opinii Ministerstwa Sprawiedliwości sprawa rozwodowa wszczęta z powództwa mariawity należy na podstawie art. 189 PM do właściwości sądu okręgowego ${ }^{20}$.

${ }^{20}$ AAN, Min. W. R. i O. P., 550/1178. Według opinii Ministerstwa Sprawiedliwości z 28 II 1920 r., obowiązujące w b. Królestwie Kongresowym prawo z 1836 r. zawiera przepisy, dotyczące poszczególnych wyznań w pierwszych czterech rozdziałach. Natomiast „w rozdziale V w art. 179-191 
Stanowisko Ministerstwa Sprawiedliwości, które uznało sąd powszechny za właściwe forum dla żony Winiarskiego, prawdopodobnie nadal katoliczki, wyraźnie nawiązywało do zapatrywania J. Gwiazdomorskiego, który prezentował pogląd, że sądy kościelne nie mogą orzekać w sprawach małżeńskich, jeżeli jedna ze stron, powód lub pozwany, należy do wyznania objętego regulacją rozdz. V (tzw. ograniczona delegacja sądów duchownych). Pozostaje z nim w zgodzie również orzeczenie sądu apelacyjnego z dnia 18 X 1923 r. w sprawie rozwodowej z powództwa katolika przeciwko marjawitce. Sąd apelacyjny orzekł, że art. 196 PM w redakcji nadanej mu zdaniem Rady Państwa rosyjskiego z 11 VI 1891 r. (Zb. Pr. i rozp. Nr 801/1891 poz. 873), głoszący, że

wyrzeczenie rzeczywistego istnienia małżeństwa i ważności tegoż należy do sądu wyznania, którego duchowny wpierw ślubu udzielił, zaś wyrok dotyczący słuszności przyczyn rozwiązania i co do samego rozwiązania stanowi sąd wyznania, do którego należy pozwany, może mieć zastosowanie do spraw o rozwiązanie małżeństwa pomiędzy osobami wyznającemi religję rzym.-kat., i osobami tych tylko innych wyznań chrześcijańskich (art. 198 PM), które posiadają sądy duchowne, skoro zaś marjawici sądów duchownych nie posiadają, do sporów o rozwiązanie małżeństwa między rzymskimi katolikami a marjawitami nie może mieć zastosowania.

W uzasadnieniu tego orzeczenia podkreślono również; że „do sporów o rozwiązanie małżeństwa między rzymskimi katolikami a marjawitami mają zastosowanie przepisy rozdz. V prawa o małż., w szczególności art. 189 PM i art. 1619 UPC", a więc zachodzi właściwość sądów ogólnych. Sąd apelacyjny uznał także, że przepis art. 189 ma charakter międzywyznaniowy, stwierdzając, że „w myśl art. 189 PM rozwód małżonków, należących do różnych wyznań chrześcijańskich, może być wyrzeczonym o ile jest dozwolony według zasad wyznania strony powodowej”21.

Powyższe rozumowanie prowadziło do wyeliminowania jurysdykcji sądu konsystorskiego w sprawach dotyczących małżeństw z osobami wyznania objętego rozdz. V. Tego stanowiska od samego początku nie podzielało jednak Ministerstwo Wyznań Religijnych i Oświecenia Publicznego, które uznało

zawarte są przepisy o małżeństwie osób, należących do wyznań nieobjętych w poprzedzających rozdziałach. Zważywszy, że art. 189 PM w związku z art. 1619 UPC stosuje się z wyjątkiem wyznań rzymsko-katolickiego, grecko-rosyjskiego, ewang.-augsburskiego i ewang.-reformowanego do wszystkich innych wyznań, że w ustawie z dnia 11 III 1912 r. o wyznawcach nauki marjawitów (...) nie zrobiono pod tym względem dla marjawitów żadnych wyjątków (por. wyrok Ogólnego Zgromadzenia Senatu Nr 15/1913), że projekty i zamierzenia rządu rosyjskiego co do urządzenia w przyszłości tego wyznania, nie mają dla danej sprawy absolutnie żadnego znaczenia, z tych względów zdaniem Min. Sprawiedliwości sprawa rozwodowa B. Winiarskiego, jako wyznawcy nauki marjawickiej i powoda, na mocy art. 189 pr. o małż. 1836 r. i art. 1619 i 1625 UPC należy do kompetencji właściwego sądu okręgowego.

${ }^{21}$ GSW, Nr 12/1924, s. 166-167. 
art. 189 PM za przepis pozbawiony charakteru międzywyznaniowego ${ }^{22}$. Poglądów Ministerstwa nie sposób jednak zaakceptować. Słusznie wprawdzie resort wyznań uznał, że art. 189 PM, zamieszczony w rozdz. V, nie dotyczy członków wyznań objętych rozdz. I-IV prawa małżeńskiego. Nie można jednak podzielić stanowiska, że przepis art. 189 PM nie miał charakteru międzywyznaniowego. Sprzeciwia się temu wyraźne brzmienie tego przepisu, który określał właściwość prawa materialnego w sprawie małżeńskiej. Przedmiotem jego regulacji było zatem rozstrzygnięcie kolizji między konkurującymi ustawami religijnymi. Chodziło więc o małżonków należących do różnych wyznań, bo tylko wtedy konkurencja taka mogła mieć miejsce. Natomiast zamieszczenie tego przepisu w rozdz. V pozwala wyciągnąć wniosek, że jego ratio legis ograniczało się do rozstrzygnięcia kolizji ustaw związków wyznaniowych, objętych rozdz. V. Kolizję tę rozstrzygnięto, uznając właściwość ustawy religijnej strony powodowej. Gdyby art. 189 PM nie miał charakteru międzywyznaniowego, wskazanie na właściwość prawa religijnego strony powodowej byłoby bezprzedmiotowe.

Poglądy zbieżne ze stanowiskiem resortu wyznań zaprezentował Sąd Najwyższy w orzeczeniu z dnia 27 XI 1931 r. (Zb. Orz. 222/1931), uznając również, że przepis art. 189 PM nie ma charakteru międzywyznaniowego, co w praktyce zawężało jego znaczenie do określenia właściwości sądu powszechnego w spra-

${ }^{22}$ AAN, Min. W. R. i O. P., 544-549/1178. Według tego resortu postanowienia art. 179 do art. 191, zatem i postanowienie powołanego w piśmie Min. Sprawiedliwości art. 189, odnoszą się do małżeństw osób, należących do wyznań nieobjętych w poprzedzających rozdziałach, zatem do osób nie będących wyznania rzymsko-katolickiego, grecko-rosyjskiego, grecko-unickiego i wyznań ewang.-augsb. i ewang.-ref., o których mówią rozdziały I do IV pr. o małż. Postanowienia art. 189 stosują się wprawdzie według decyzji Senatu Nr 15 ex 1913 i do spraw o rozwiązanie małżeństw marjawitów z uwagi jednakże na to, że cały rozdział V odnosi się wyłącznie do małżeństw osób, należących wprawdzie do wyznań nieobjętych w poprzedzających rozdziałach, ale będących tego samego wyznania, nie mają zastosowania w przedmiotowem przypadku, w którym powód Winiarski jest obecnie wyznania marjawickiego, pozwana jednak żona była w chwili zawarcia związku małżeńskiego, podobnie jak powód, wyznania rzymsko-katolickiego, a obecnie ma być (według nie popartego dowodami twierdzenia powoda) wyznania mahometańskiego, zatem nie jest marjawitką. W niniejszym przypadku mogą mieć zastosowanie wyłącznie postanowienia rozdziału VI prawa o małż., a w szczególności art. 196 w redakcji prawa z 11 VI 1891 r., a to tembardziej, że decyzja Senatu Nr 15 ex 1913 głosi wyraźnie, że art. 196 stosuje się i do takich małżeństw, w których jedna ze stron jest wyznania marjawickiego. Jasno mówi dalej powyższa decyzja, że: ,jeżeli przeto jeden z małżonków jest katolikiem, a drugi marjawitą, to sprawy o rozwiązanie małżeństwa podlegają rozpoznaniu sądu tego wyznania, do którego należy pozwany. A więc jeżeli pozwany jest katolikiem, to sprawa o rozwiązanie małżeństwa należy do kompetencji biskupa diecezji, a jeżeli pozwany jest marjawitą - do sądu cywilnego. W niniejszym wypadku powód jest obecnie marjawitą, a pozwana musi być, aż do czasu dostarczenia dowodów, że przyjęła wiarę mahometańską, uważana nadal za katoliczkę, wobec czego sprawa o rozwiązanie ich małżeństwa, podlegałaby w chwili obecnej w myśl powyżej decyzji senatu rozpoznaniu biskupa katolickiego diecezji. Gdyby jednak nawet Winiarski dostarczył dowody, że żona jego jest obecnie mahometanką, to i w tym wypadku nie mogłyby mieć zastosowania postanowienia rozdziału $\mathrm{V}$ pr. o małż., ponieważ i w tym razie nie byli tak powód, jak i pozwana tego samego wyznania, lecz należeliby do dwóch różnych wyznań". 
wie pomiędzy małżonkami należącymi do tego samego wyznania, objętego regulacją rozdz. $\mathrm{V}^{23}$. Niemniej, właściwość tego sądu w sprawie małżeństwa osób wyznania mariawickiego, mahometańskiego bądź mojżeszowego wynikała już z samego faktu, że prawo małżeńskie z 1836 r. wyraźnie przyznało jurysdykcję w sprawach małżeńskich tylko wyznaniom uregulowanym w rozdz. I-IV. Poza tym pogląd SN, że prawo małżeńskie z 1836 r. określiło jedynie właściwości sądu w ramach małżeństw katolicko-sektanckich, bo art. 198 PM odsyłał w tej kwestii do art. 196 PM, prowadzi do wniosku, że w przypadku pozostałych małżeństw mieszanych z udziałem sektantów ustawodawca nie wskazał forum sądowego.

Interesujący jest także kolejny wniosek SN, a mianowicie SN przeszedł do porządku dziennego nad faktem, że w rezultacie decyzji papieskich w sprawie małżeńskiej z powództwa sektanta przeciw katolikowi forum sądowe, wskazane przez art. 196 PM w Polsce w ogóle nie istniało ${ }^{24}$. Takiej sytuacji nie przewidywał nawet rząd rosyjski, określający po zawarciu konkordatu tok instancji sądowej dla spraw małżeńskich katolików. Zdanie Rady Państwa z dnia 5 lipca 1856 r. (Dz. Pr. L. 77), przewidywało bowiem, że sąd Stolicy

${ }^{23}$ W orzeczeniu z dnia 27 XI 1931 r. Sąd Najwyższy rozpoznawał pytanie prawne, wynikłe w sprawie ze skargi kasacyjnej Marji M. przeciwko Aleksandrowi M. o uznanie małżeństwa za rozwiązane i na zasadzie $\S 1$ art. 40 USP przedstawione do rozstrzygnięcia składowi siedmiu sędziów: czy sąd cywilny jest właściwy do rozpoznania powództwa o rozwiązanie małżeństwa pomiędzy osobami, z których strona pozywająca należy do wyznania chrześcijańskiego, nieobjętego rozdziałami I-IV PM, a strona pozwana do wyznania rzymsko-katolickiego, kiedy ślub religijny dopełniony został przez duchownego akatolickiego, po dopełnieniu zaś obrzędu sporządzony był akt cywilny? Według SN art. 179 i 189 mają na względzie sprawy małżeńskie chrześcijan-sektantów, gdy obie strony należą do tego samego wyznania, nie regulują jednak przypadków, gdy chodzi o małżeństwa, w których jedna tylko ze stron należy do jednego z wyżej wzmiankowanych wyznań chrześcijańskich, druga jest zaś wyznania rzymsko-katolickiego, nie mają, przeto wprost zastosowania do przypadku, zachodzącego w postawionym na czele pytaniu. Według postanowienia art. 198 PM, zasady przewidziane dla małżeństw mieszanych ewangelicko-katolickich mają zastosowanie do małżeństw pomiędzy katolikami a chrześcijanami-sektantami. A zatem stosuje się względem nich również art. 196 PM.

${ }^{24}$ W motywach orzeczenia z dnia 27 XI 1931 r. czytamy: „W myśl art. 196, chociażby obrzęd ślubu był dopełniony w kościołach obu wyznań, wyrok dotyczący słuszności przyczyn rozwiązania małżeństwa i co do samego rozwiązania stanowi sąd wyznania, do którego należy pozwany; dosłowne brzmienie tego przepisu wskazuje, iż kwestję rozwiązania małżeństwa decyduje zawsze sąd wyznania, do którego należy strona pozwana; przepis ten jako stanowczy i nie nasuwający żadnych wątpliwości, nie wymaga żadnej wykładni, wszelka zaś wykładnia, która prowadziłaby do wręcz sprzecznego z nim rozstrzygnięcia, jest niedopuszczalna. Wobec tego postawione na czele pytanie należy rozstrzygnąć w sensie przeczącym. Okoliczność, iż według nowego prawa kanonicznego (zatwierdzona przez Papieża wykładnia Kongregacji S. Officii, ogłoszona w t. XX Acta Apostolicae Sedis z dnia 1 marca 1928) strona akatolicka nie może wystąpić w sprawach małżeńskich w charakterze powoda przed zwykły sąd duchowny, istniejący w każdej diecezji, lecz w wyjątkowych wypadkach może zwrócić się do Kongregacji Sancti Officii, która jest wyłącznym sądem właściwym do rozpoznawania tego rodzaju spraw, nie zmienia postaci rzeczy, forum bowiem do rozpoznawania tych spraw istnieje, trudności zaś, z któremi połączone jest wystąpienie dla strony akatolickiej pozostają w związku z ogólnym stanowiskiem Prawa o Małżeństwie 1836r. w kwestji rozwiązania małżeństwa”. 
Apostolskiej będzie orzekał dopiero w trzeciej instancji w sprawie odwołań od wyroków zapadłych w sądach kościelnych mających siedzibę w Królestwie Kongresowym. Natomiast po odzyskaniu niepodległości powstała sytuacja, że żaden katolicki sąd kościelny w Polsce nie był właściwy do rozstrzygnięcia sprawy z powództwa sektanta zarówno w pierwszej, jak i w kolejnych instancjach. Według prawa kanonicznego sąd właściwy w tej sprawie znajdował się bowiem w Stolicy Apostolskiej.

Okoliczność z powyższego wynikająca, a mianowicie brak w Polsce dla obywatela polskiego forum sądowego, SN zaakceptował, powołując się na prawo małżeńskie z 1836 r., które rzekomo sytuację tego rodzaju przewidywało. Stanowisko SN godziło w zasadę suwerenności państwa polskiego. Było także nie do pogodzenia z procedurą rosyjską. Brak właściwego sądu kościelnego nie mógł bowiem prowadzić do wniosku, że w kraju w ogóle nie ma właściwego sądu w przedmiocie praw stanu obywatela polskiego wyznania sektanckiego. W takich sytuacjach zachodziła bowiem kompetencja sądu powszechnego (art. $1 \mathrm{w}$ zw. z art. 9 UPC). Według art. 1 UPC sądy powszechne obowiązane były rozpatrywać każdy spór cywilny. Rola tego przepisu polegała więc na wypełnieniu potencjalnej luki kompetencyjnej. Odnośnie do art. 9 UPC, SN zajął stanowisko, że nawet $\mathrm{w}$ razie zupełnego braku odpowiedniej ustawy sąd jest obowiązany wyrokować na ogólnych zasadach prawa (Zb. Orz. Nr 201/1938).

Małżeństwa niechrześcijańskie nie wywoływały w okresie międzywojennym sporów ideologicznych. Małżeństwa chrześcijan-sektantów były w gorszej sytuacji. W II Rzeczypospolitej pojawiły się rozbieżności stanowisk w przedmiocie właściwości sądu w sprawie rozwodowej, jeżeli przynajmniej jedna ze stron należała do wyznania objętego rozdz. V. Problem pojawiał się zwłaszcza, gdy drugi małżonek był wyznania katolickiego.

W II Rzeczypospolitej kontrowersje wywoływała w szczególności kwestia właściwości sądu w sprawach małżeństw pierwotnie katolickich, gdy jeden z małżonków przyjął następnie wyznanie protestanckie. Przypadki przejścia na wyznanie objęte regulacją rozdz. V nie były jednak tak częste jak przyjęcie wyznania ewangelicko-augsburskiego lub ewangelicko-reformowanego. W razie przyjęcia wyznania niechrześcijańskiego przez obu małżonków, rozpoznanie sprawy małżeńskiej należało do sądu właściwego dla ich nowego wyznania. Ponieważ wszystkie wyznania niechrześcijańskie pozbawiono jurysdykcji w sprawach małżeńskich, właściwym był wyłącznie sąd cywilny. Sąd cywilny właściwy był także wtedy, gdy współmałżonkowie - pomimo zmiany wyznania przez jednego z nich - nadal należeli do religii nieobjętych jurysdykcją duchowną. Jeszcze dalej idące stanowisko prezentowało we wzmiankowanej opinii z lutego 1920 r. Ministerstwo Sprawiedliwości, uznając sąd cywilny za kompetentny w każdym przypadku, gdy powodem była osoba wyznania objętego rozdz. V (art. 189 PM). Przeciwnie, według Ministerstwa W. R. i O. P., przepis ten nie miał w ogóle zastosowania w sprawach małżeństw mieszanych. 